\title{
Synthesis, Structure and some Reactions of a Multi-bridged Unsaturated Cyclooctadecane Derivative Formally Having Two Cycloheptatrienes
}

\author{
Shigeyasu KURODA, ${ }^{\mathrm{a}^{*}}$ Isao HIRANO, ${ }^{\mathrm{a}}$ Yanmei ZHANG, ${ }^{\mathrm{a}}$ Nguyen Chung THANH, ${ }^{\mathrm{a}}$ and Mitsunori \\ $\mathrm{ODA}^{\mathrm{b}^{*}}$ \\ ${ }^{\text {a }}$ Department of Applied Chemistry, Faculty of Engineering, University of Toyama, \\ Gofuku 3190, Toyama, Japan. 930-8555 \\ ${ }^{\mathrm{b}}$ Department of Chemistry, Faculty of Science, Shinshu University, Asahi 3-1-1, Matsumoto, \\ Nagano, Japan 390-8621
}

\begin{abstract}
Double annulation of 1,6-bis(bromomethyl)-1,3,5cycloheptatriene with diethyl acetonedicarboxylate under basic conditions provided the title cyclooctadecane derivative having formally two 1,3,5cycloheptatriene moieties. An NMR study of the compound suggested that one moiety stays as a cycloheptatriene form and the other as a norcaradiene form. X-ray crystallographic analysis revealed that two methano bridges have syn- and anti-configurations to the central carbonyl bridge and also showed that one of the moieties having the syn-methano bridge stays a CHT form and the other having the anti-methano bridge stays an NCD form.
\end{abstract}

Keywords: cycloheptatriene-norcaradiene equilibrium; X-ray crystallographic analysis; semiempirical molecular orbital calculation; annulation

*Corresponding author: Tel \& Fax: + 8176445 6819; e-mail: kuro@eng.u-toyama.ac.jp

Over the last forty years since the first review on norcaradienes written by G. Maier in 1967 up to now, ${ }^{1}$ many papers on a cycloheptatriene $(\mathrm{CHT}, \mathbf{1})$-norcaradiene $(\mathrm{NCD}, 2)$ equilibrium (called also tautomerism or valence isomerization) have appeared, ${ }^{2,3}$ proving that there is continuing interest in this subject in organic chemistry. In general, CHT is thermodynamically more stable than NCD which has a strained cyclopropane ring. Thus, the equilibrium shifts to the side of CHT. However, electronic and conjugative effects by a substituent around the carbon skeleton can shift the equilibrium to the reverse side. ${ }^{4}$ Besides those effects, a peculiar structural constraint of molecules can affect the equilibrium., ${ }^{5,6}$ While tetra- and pentamethylene bridges at the 1,6positions of CHT do not affect the equilibrium in $\mathbf{4}$ and 5, a trimethylene bridge constricts the carbon atoms at the 1,6-positions to freeze the NCD form in 3 (Chart 1). ${ }^{6}$ This tendency can be seen in the structure of an anti-type of doubly methano-bridged dihydro[14]annulene 6 having the 
partial structure of 5; both cycloheptatriene moieties in $\mathbf{6}$ stay as the CHT form. ${ }^{7}$ Therefore, we expected that the title compound 7, diethyl tetracyclo[8.8.1.1 $\left.1^{3,8} \cdot 1^{12,17}\right]$ henicosa-3,5,7,12,14,16hexaen-19-one-1,10-dicarboxylate, would have two CHT forms whatever stereochemical relationship between the bridges it has. Herein we describe the synthesis, actual structure and some reactions of 7 .

\section{Scheme 1}

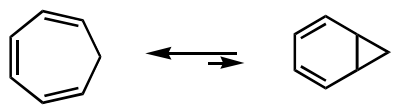

1

2

\section{Chart 1}

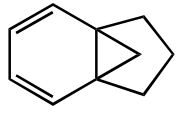

3

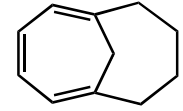

4

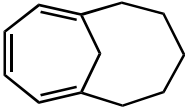

5

Chart 2

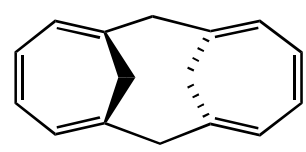

6

\section{Chart 3}

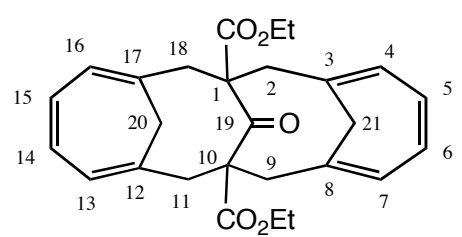

7

The title compound 7 was synthesized by double annulation of diethyl acetonedicarboxylate (9) with 1,6-bis(bromomethyl)-1,3,5-cycloheptatriene $(\mathbf{8})^{8}$ under basic conditions either by a one-pot procedure or in a stepwise way. ${ }^{9}$ The yield of the latter method was found to be slightly better than that of the former. It is worthy to note that only one stereoisomer was obtained as a product in these annulations (vide infra). Based on analysis of the NMR spectra, the gross structure of this product was estimated to have one CHT form and one NCD form. The ${ }^{1} \mathrm{H}$ NMR spectrum of the product showed signals for four pairs of methylene protons in addition to signals of four olefinic protons and two ethyl ester groups. Among the four, two pairs with a twofold signal height to others are assigned for the methylenes on the principal ring. One of the two remaining pairs at $\delta$ 1.42 and $2.42 \mathrm{ppm}$ with a smaller signal height has a coupling constant of $12.0 \mathrm{~Hz}$ and can be assigned to the methylene bridge of a CHT form, and the other at $\delta \quad-0.22$ and $1.18 \mathrm{ppm}$ has a 
coupling constant of $3.4 \mathrm{~Hz}$ and can be assigned to the cyclopropane methylene of an NCD form. Thus, the result clearly indicates that the product has both forms, contrary to our prediction. In order to clarify the exact structure of the product, an X-ray crystallographic structure analysis was carried out. ${ }^{10}$ Single crystals of 7 were obtained by recrystallization from a mixture of dichloromethane and hexane at room temperature. Its ORTEP drawings are shown in Fig. 1. The crystal structure shows that the C-20 methano bridge has syn-configuration to the C-19 carbonyl bridge and the $\mathrm{C}-21$ methano bridge has anti-configuration and the right-wing cycloheptatriene part of the structure 7 was found to stay as the NCD form. Thus the compound does not have the structure of $7 \mathbf{a}$ but that of $7 \mathbf{b}$ shown in Chart 4 .

\section{Scheme 2}

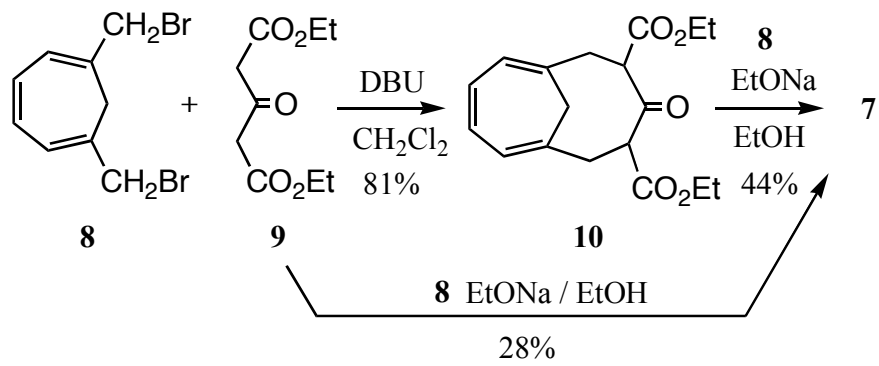

Figure 1. ORTEP drawings of 7.
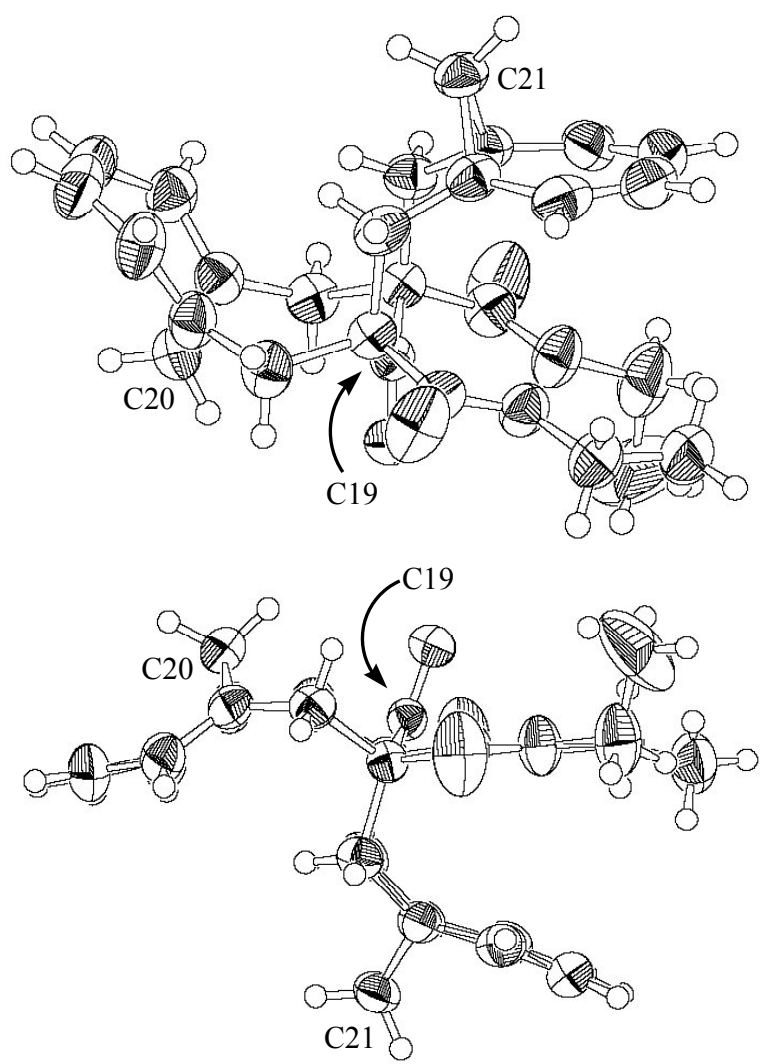


\section{Chart 4}

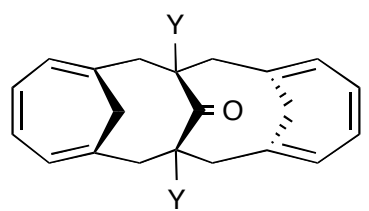

$\mathrm{Y}=\mathrm{CO}_{2} \mathrm{Et} ; \mathbf{7 a}$

$=\mathrm{H} ; 12 \mathrm{a}$

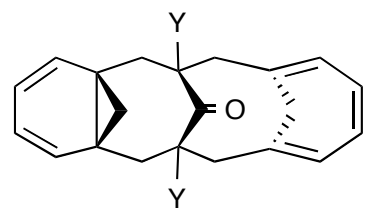

$\mathrm{Y}=\mathrm{CO}_{2} \mathrm{Et} ; \mathbf{7 c}$

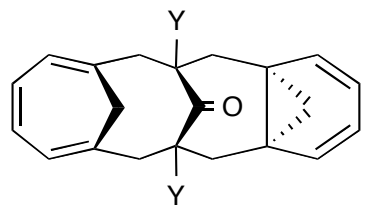

$\begin{aligned} \mathrm{Y} & =\mathrm{CO}_{2} \mathrm{Et} ; \mathbf{7} \mathbf{b} \\ & =\mathrm{H} ; \mathbf{1 2}\end{aligned}$

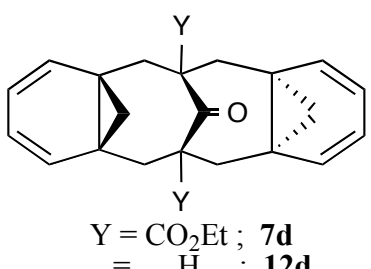

The stereoselectivity leading to the configuration between the carbonyl group and two methano bridges can be rationalized by the following facts derived from PM3 semi-empirical molecular orbital calculations; ${ }^{11} 1$ ) There are two syn- and anti-enolate anions 11 of bicyclo[5.4.1]dodeca7,9,11-trien-4-one, instead of its actual diester enolate, which are possible as an intermediate in the second annulation. Among them the syn-enolate is predicted to be slightly more stable than the anti- enolate. $^{12}$ 2) The syn-enolate has only enough room at the opposite side to the methano bridge for an electrophilic attack as shown in Fig. 2. The stereoselectivity of the anti-configuration between the carbonyl and C-21 methano bridges may be controlled by minimizing the steric hindrance between the enolate oxygen and the methylene protons at the 7 position of 8 in the alkylation reaction of the enolate.

Figure 2. The optimized structures of syn- and anti-enolate anions $\mathbf{1 1 .}$
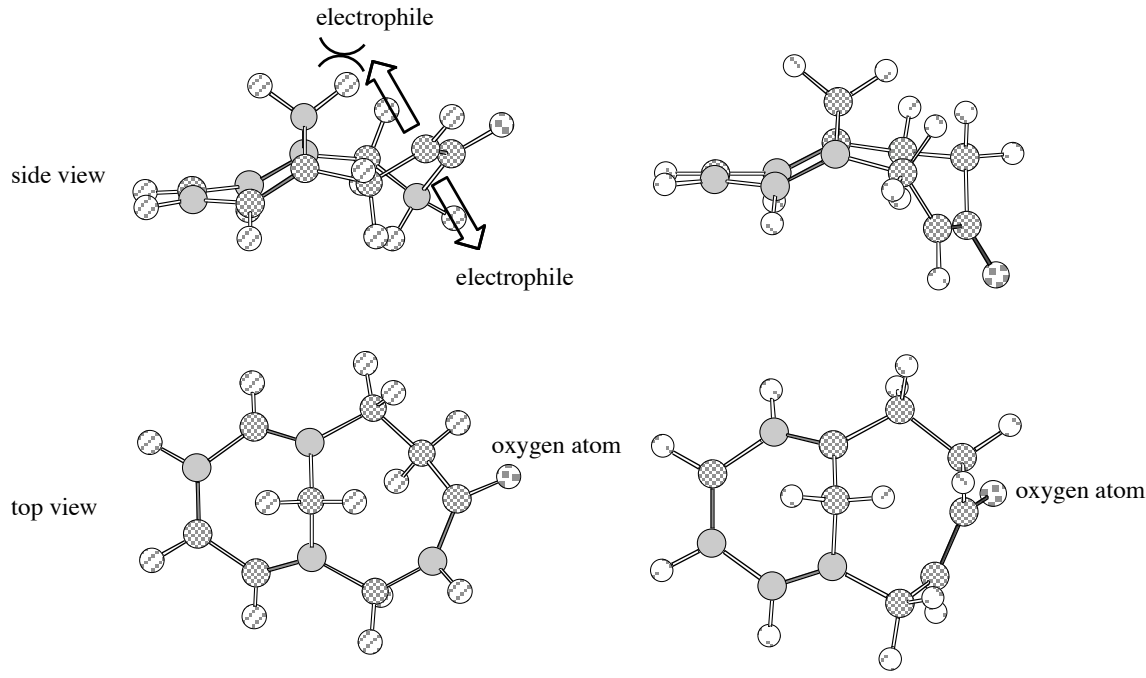

syn-11

anti-11

There are four possible valence isomers, 7a-d, for a stereoisomer having the syn- and anti- 
configurations. Semi-empirical molecular orbital calculations of the norester compound 12, as a simplified model for $\mathbf{7}$, predict that $\mathbf{1 2 b}$ is the most stable as shown in Fig. 3. ${ }^{13}$ The carbon skeleton of tetracyclo[8.8.1.1 $\left.1^{3,8} \cdot 1^{12,17}\right]$ henicosa-3,5,7,12,14,16-hexaen-19-one in 12a has two cyclooctanone moieties, one of which appears like a crown form through the 19-1-18-17-20-1211-10 carbons and the other like a slightly spread boat-chair form through the 19-1-2-3-21-8-9-10 carbons. The latter conformation is unusual as a conformer of eight-membered rings. ${ }^{14} \mathrm{~A}$ combination of two components creates a peculiar structure with a relatively long atomic distance between the 11 and 18 carbon atoms and a relatively short atomic distance between the 2 and 9 carbon atoms; in the calculated structure of 12a, the former distance is $3.939 \AA$ long and the latter is $3.353 \AA$. The constraint of the latter short distance may favor the NCD form at the right wing of this molecule.

Figure 3. The optimized structures of 12a-d. The values in parentheses are relative heats of formation in $\mathrm{kcal} \mathrm{mol}^{-1}$.

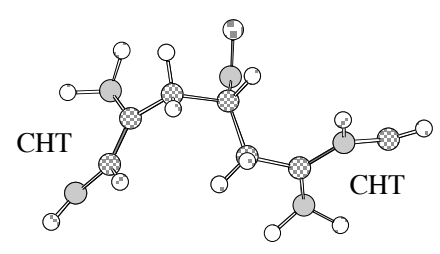

12a (1.33)

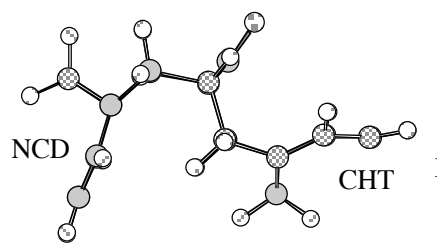

12c (7.72)

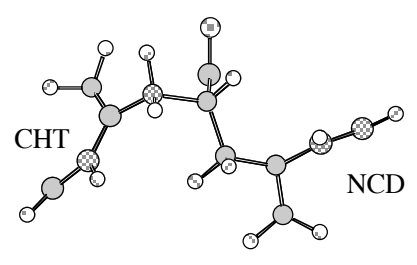

$12 \mathbf{b}(0)$

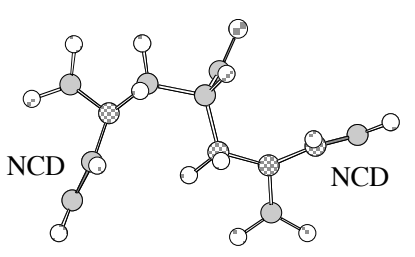

12d (11.69)

Some chemical behavior of $\mathbf{7 b}$ was also studied. The reaction of $\mathbf{7 b}$ with 4-phenyl-1,2,4-triazoline3,5-dione (PTAD) at room temperature gave the [4+2]adduct 13 in a quantitative yield. An excess of PTAD for a prolonged reaction time at the same temperature resulted in only production of $\mathbf{1 3}$, indicating clear reluctance of the cycloheptatriene moiety for the cycloaddition and also that the equilibrium of the left-wing part shifts far to the side of the CHT form in 13. The crystal structure of $\mathbf{1 3}$ was also elucidated by X-ray analysis. ${ }^{11}$ The ORTEP drawing of $\mathbf{1 3}$ is shown in Fig. 4. Thermolysis of $\mathbf{7}$ in refluxing dimethylsulfoxide gave the normethylene product $\mathbf{1 4}$ as seen in other norcaradiene compounds. ${ }^{2 a}$ Hydrolysis and subsequent decarboxylation provided 12b whose structure was confirmed by spectroscopic analysis to have similarly both CHT and NCD forms as predicted by the calculations. 

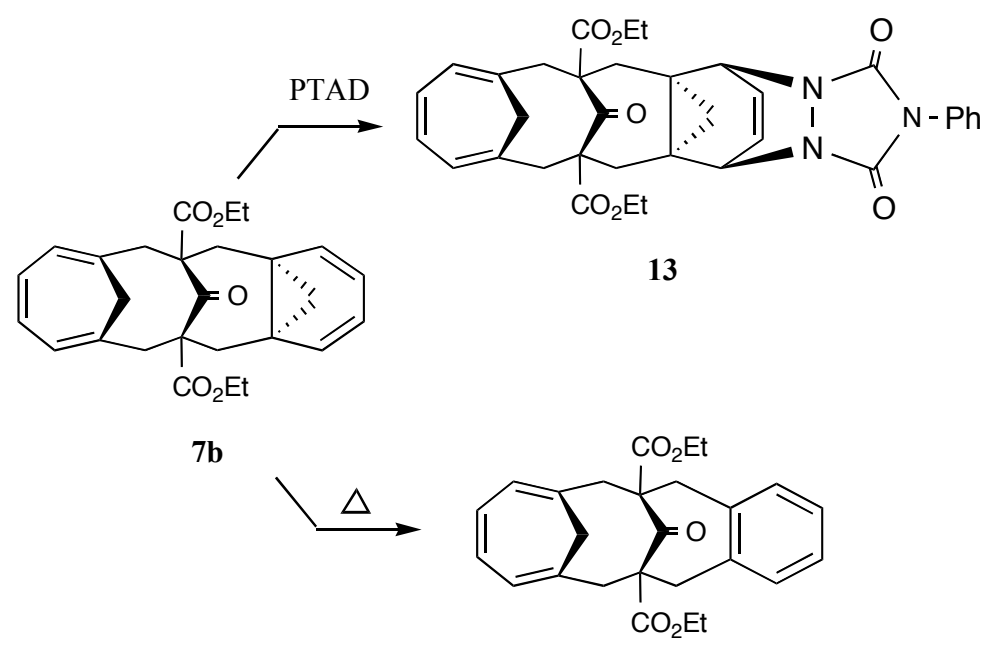

14

\section{Scheme 4}

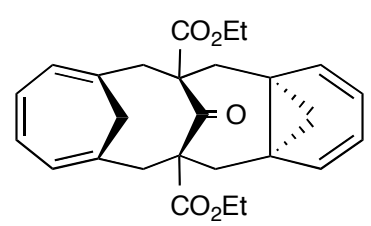

$7 \mathbf{b}$

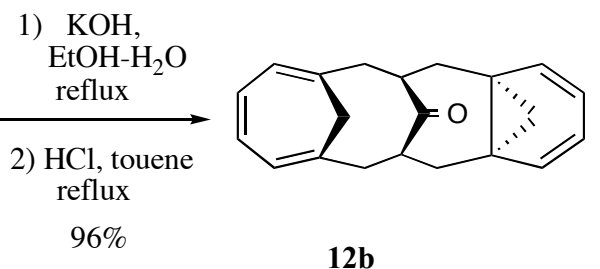

$12 \mathrm{~b}$

Figure 4. The crystal structure of 13. A view along the short molecular axis.

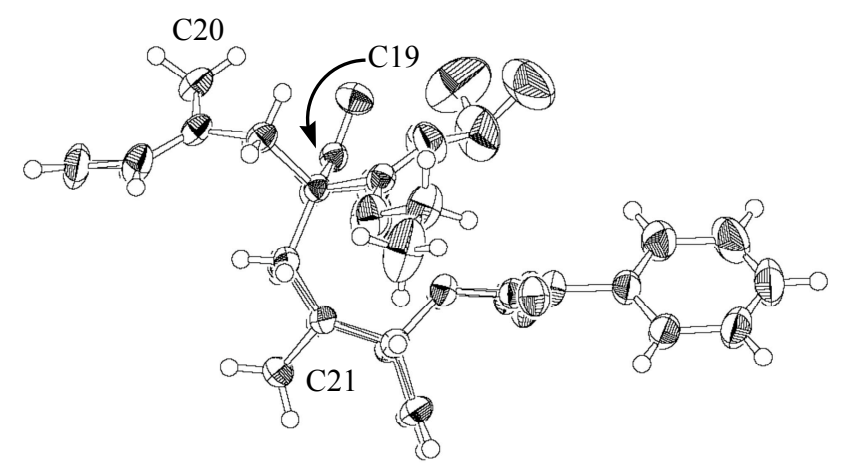

\section{Acknowledgements}

We deeply thank Rigaku Inc. for X-ray crystallographic analysis of the title compound and its cycloaddition product.

\section{References and Notes}

1. Maier, G. Angew. Chem., Int. Ed. Engl. 1967, 6, 402-413.

2. For reviews on this subject, see; a) Vogel, E. Pure Appl. Chem. 1969, 20, 237-262; b) Toda, T. J. Synth. Org. Chem. Jpn. (Yuki Gosei Kagaku Kyoukai Shi) 1972, 30, 412-423; c) le 
Noble, W. J. Highlights of Organic Chemistry, ch. 11, pp402-406, Marcel Dekker Inc., New York, 1974; d) Takeuchi, K. J. Synth. Org. Chem. Jpn. (Yuki Gosei Kagaku Kyoukai Shi) 1985, 43, 41-54; e) Balci, M. Turk. J. Chem. 1992, 16, 42-90.

3. For recent papers on this subject, see; a) Saracoglu, N.; Talaz, O.; Azizoglu, A.; Watson, W. H.; Balci, M. J. Org. Chem. 2006, 70, 5403-5408; b) Minegishi, S.; Kamada, J.; Takeuchi, K.; Komatsu, K.; Kitagawa, T. Eur. J. Org. Chem. 2003, 3497-3504; c) Freccero, M.; Gandolfi, R.; Sarzi-Amade, M.; Bovio, B. Eur. J. Org. Chem. 2002, 569-579; d) Maguire, A.R.; O’Leary, P.; Harrington, F.; Lawrence, S. E.; Blake, A. J. J. Org. Chem. 2001, 66, 7166-7177; e) Kitagawa, T.; Kamada, J.; Minegishi, S.; Takeuchi, K. Org. Lett. 2000, 2, 3011-3013; f) Gridnev, H. D.; Tok, O. L.; Gridneva, N. A.; Bubnov, Y. N.; Schreiner, P. R. J. Am. Chem. Soc. 1998, 120, 1034-1043; g) Oda, M.; Kuroda, S. Recent Res. Develop. Pure \& Appl. Chem. 1998, 2, 145-155; h) Nitta, M.; Takayasu, T. J. Chem. Soc. Perkin Trans. 1 1998, $1325-1334$.

4. a) Vogel, E.; Wiedemann, W.; Kiefer, H.; Harrison, W. F. Tetrahedron Lett. 1963, 673-678;

b) Vogel, E.; Wiedemann, W.; Roth, H. D.; Eimer, J.; Guenther, H. Liebigs Ann. 1967, 759, $1-17$.

5. For recent aspects of the electronic effect, see ref $3 f$ and following papers; a) Matsumoto, M.; Shiono, T.; Mutoh, H.; Amano, M.; Arimitsu, S. Chem. Commun. 1995, 101-102; b) Matsumoto, M.; Shiono, T.; Kasuga, N. C. Tetrahedron Lett. 1995, 36, 8817-8820.

6. For the other structural effects, see; a) Kohmoto, S.; Funabashi, T.; Nakyama, N.; Nishio, T.; Iida, I.; Kishikawa, K.; Yamamoto, M.; Yamada, K. J. Org. Chem. 1993, 58, 4764-4766; b) Oda, M.; Horiguchi, H.; Masaki, Y.; Sakamoto, Y.; Kuroda, S. Recl. Trav. Chim. Pays-Bas 1996, 115, 149-150; c) Prinzbach, H.; Fischer, U. Helv. Chim. Acta 1967, 50, 1692-1722.

7. a) Vogel, E.; Biskup, M.; Vogel, A.; Haberland, U.; Eimer, J. Angew. Chem., Int. Ed. Engl. 1966, 5, 603-604; b) Vogel, E.; Haberland, U.; Günther, H. Angew. Chem., Int. Ed. Engl. 1970, $9,513-514$.

8. $\quad$ Farrant, G. C.; Feldmann, R. Tetrahedron Lett. 1970, 4979-4982.

9. The one-pot procedure for 7 is as follows; To a solution of $30 \mu 1(0.72 \mathrm{mmol})$ of 9 and 166 $\mathrm{mg}$ of sodium ethoxide in $30 \mathrm{ml}$ of ethanol was added $399 \mathrm{mg}(1.44 \mathrm{mmol})$ of $\mathbf{8}$ and $5 \mathrm{ml}$ of dichloromethane at room temperature. After being stirred for $1 \mathrm{hr}$, the resulted mixture was concentrated and poured into $50 \mathrm{ml}$ of $1 \mathrm{M}$ hydrochloric solution which was extracted with dichloromethane $(100 \mathrm{ml} \times 2)$. The combined organic layer was washed with a saturated $\mathrm{NaHCO}_{3}$ aq. solution and brine, and was dried over anhydrous $\mathrm{MgSO}_{4}$. The solvent was removed and the residue was crystallized from dichloromethane-hexane to give $86 \mathrm{mg}$ (28\% yield) of 7 as colorless prisms. All new compounds were characterized by spectroscopic and combustion analyses. The proton signals in the ${ }^{1} \mathrm{H}$ NMR spectrum were assigned with the aid of NOE experiments. Selected data are as follows. 7: $\mathrm{Mp}=158-160{ }^{\circ} \mathrm{C},{ }^{1} \mathrm{H}$ NMR 
$\left(\mathrm{CDCl}_{3}\right) \delta=-0.22(\mathrm{~d}, J=3.4 \mathrm{~Hz}, 1 \mathrm{H}$, one of $\mathrm{H}-21), 1.18(\mathrm{~d}, J=3.4 \mathrm{~Hz}, 1 \mathrm{H}$, one of H-21), $1.23\left(\mathrm{t}, J=7.2 \mathrm{~Hz}, 6 \mathrm{H}, \mathrm{OCH}_{2} \mathrm{CH}_{3}\right), 1.39(\mathrm{~d}, J=16.1 \mathrm{~Hz}, 2 \mathrm{H}$, one of H-2,9), $1.42(\mathrm{~d}, J=$ $12.0 \mathrm{~Hz}, 1 \mathrm{H}$, one of H-20), 2.28 (d, $J=16.1 \mathrm{~Hz}, 2 \mathrm{H}$, one of $\mathrm{H}-2,9), 2.42(\mathrm{~d}, J=12.0 \mathrm{~Hz}, 1 \mathrm{H}$, one of H-20), 2.65 (d, $J=12.0 \mathrm{~Hz}, 2 \mathrm{H}$, one of H-11,18), 3.01 (d, $J=12.0 \mathrm{~Hz}, 2 \mathrm{H}$, one of H11,18 ), 3.93 (dq, $J=11.0,7.2 \mathrm{~Hz}, 2 \mathrm{H}$, one of $\left.\mathrm{OCH}_{2} \mathrm{CH}_{3}\right), 4.25(\mathrm{dq}, J=11.0,7.2 \mathrm{~Hz}, 2 \mathrm{H}$, one of $\mathrm{OCH}_{2} \mathrm{CH}_{3}$ ), 5.66 (m, 2H, H-4,7), 5.77 (m, 2H, H-5,6), 6.03 (brs, 2H, H-13,16), 6.60 $(\mathrm{m}, 2 \mathrm{H}, \mathrm{H}-14,15) \mathrm{ppm} ;{ }^{13} \mathrm{C} \mathrm{NMR}\left(\mathrm{CDCl}_{3}\right) \delta=13.8,24.9,31.5,39.0,39.5,49.3,61.3,67.3$, 118.8, 125.8, 127.4, 129.7, 130.7, 174.1, 208.8 ppm; HRMS calcd for $\mathrm{C}_{27} \mathrm{H}_{30} \mathrm{O}_{5}$ 434.2093, obsd 434.2020; IR (KBr) $v_{\max }=1720 \mathrm{~s}, 1710 \mathrm{~s}, 1690 \mathrm{~s}, 1280 \mathrm{~s}, 1240 \mathrm{~s}, 1200 \mathrm{~s}, 1050 \mathrm{~s}, 750 \mathrm{~s}$, $730 \mathrm{~s} \mathrm{~cm}^{-1}$; UV (MeOH) $\lambda_{\max }=207(\log \varepsilon=4.39), 273$ (3.79) nm. 13: Colorless plates, mp $=228-229{ }^{\circ} \mathrm{C},{ }^{1} \mathrm{H}$ NMR $\left(\mathrm{CDCl}_{3}\right) \delta=0.11(\mathrm{~d}, J=5.8 \mathrm{~Hz}, 1 \mathrm{H}), 0.72(\mathrm{~d}, J=5.8 \mathrm{~Hz}, 1 \mathrm{H}), 1.26$ (t, $J=7.2 \mathrm{~Hz}, 6 \mathrm{H}), 1.37(\mathrm{~d}, J=11.1 \mathrm{~Hz}, 2 \mathrm{H}), 1.38$ (d, $J=16.1 \mathrm{~Hz}, 2 \mathrm{H}), 2.44(\mathrm{~d}, J=11.2 \mathrm{~Hz}$, 2H), $2.57(\mathrm{~d}, J=11.1 \mathrm{~Hz}, 1 \mathrm{H}), 2.85(\mathrm{~d}, J=16.1 \mathrm{~Hz}, 2 \mathrm{H}), 3.20$ (d, $J=11.2 \mathrm{~Hz}, 2 \mathrm{H}), 4.30$ (dq, $J=10.5,7.2 \mathrm{~Hz}, 2 \mathrm{H}), 4.34$ (dq, $J=10.5,7.2 \mathrm{~Hz}, 2 \mathrm{H}), 5.03$ (m, 2H), 6.01 (brs, 2H), 6.07 (m, 2H), $6.61(\mathrm{~m}, 2 \mathrm{H}), 7.35(\mathrm{~m}, 5 \mathrm{H}) \mathrm{ppm} ;{ }^{13} \mathrm{C} \mathrm{NMR}\left(\mathrm{CDCl}_{3}\right) \delta=14.0,18.1,27.2,32.8,38.9$, $52.8,57.2,62.3,66.4,125.5,126.5,126.7,127.2$, 128.3, 129.1, 129.9, 131.2, 157.2, 171,3, $200.7 \mathrm{ppm}$; IR $(\mathrm{KBr}) v_{\max }=1780 \mathrm{~s}, 1750 \mathrm{~s}, 1720 \mathrm{~s}, 1710 \mathrm{~s}, 1400 \mathrm{~s}, 1260 \mathrm{~s}, 1230 \mathrm{~s}, 1180 \mathrm{~s}$, $1020 \mathrm{~s} \mathrm{~cm}^{-1}$. 14: Colorless needles, $\mathrm{mp}=159-160{ }^{\circ} \mathrm{C},{ }^{1} \mathrm{H}$ NMR $\left(\mathrm{CDCl}_{3}\right) \delta=0.94(\mathrm{t}, J=7.1$ $\mathrm{Hz}, 6 \mathrm{H}), 1.66$ (d, $J=12.1 \mathrm{~Hz}, 1 \mathrm{H}), 2.39$ (d, $J=14.6 \mathrm{~Hz}, 2 \mathrm{H}), 2.61$ (d, $J=12.1 \mathrm{~Hz}, 1 \mathrm{H})$, $2.81(\mathrm{~d}, J=12.0 \mathrm{~Hz}, 2 \mathrm{H}), 3.23(\mathrm{~d}, J=12.0 \mathrm{~Hz}, 2 \mathrm{H}), 3.26$ (d, $J=14.6 \mathrm{~Hz}, 2 \mathrm{H}), 3.94$ (q, $J=$ $7.1 \mathrm{~Hz}, 4 \mathrm{H}), 6.17$ (brs, 2H), $6.65(\mathrm{~m}, 2 \mathrm{H}), 6.96(\mathrm{~m}, 2 \mathrm{H}), 7.11(\mathrm{~m}, 2 \mathrm{H}) \mathrm{ppm} ;{ }^{13} \mathrm{C} \mathrm{NMR}$ $\left(\mathrm{CDCl}_{3}\right) \delta=13.8,37.0,39.3,48.1,61.0,66.5,125.6,126.9,127.9,129.4,129.8,136.7$, 172.8, 209.4 ppm; IR (KBr) $v_{\max }=1722 \mathrm{~s}, 1682 \mathrm{~s}, 1270 \mathrm{~s}, 1224 \mathrm{~s}, 1193 \mathrm{~s}, 753 \mathrm{~s} \mathrm{~cm}^{-1} . \mathbf{1 2 b}$ : Colorless needles, $\mathrm{mp}=137-139{ }^{\circ} \mathrm{C},{ }^{1} \mathrm{H}$ NMR $\left(\mathrm{CDCl}_{3}\right) \delta=-0.20(\mathrm{~d}, J=3.9 \mathrm{~Hz}, 1 \mathrm{H}), 1.28$ $(\mathrm{dd}, J=15.0,13.4 \mathrm{~Hz}, 2 \mathrm{H}), 1.43(\mathrm{~d}, J=3.9 \mathrm{~Hz}, 1 \mathrm{H}), 1.58$ (d, $J=12.2 \mathrm{~Hz}, 1 \mathrm{H}), 1.88$ (dd, $J=$ 15.0, $5.6 \mathrm{~Hz}, 2 \mathrm{H}), 2.35$ (dd, $J=11.7,3.3 \mathrm{~Hz}, 2 \mathrm{H}), 2.40$ (d, $J=12.2 \mathrm{~Hz}, 1 \mathrm{H}), 2.83(\mathrm{~m}, 2 \mathrm{H})$, $2.88(\mathrm{~d}, J=11.7,4.3 \mathrm{~Hz}, 2 \mathrm{H}), 5.83(\mathrm{~m}, 2 \mathrm{H}), 5.85$ (m, 2H), 5.96 (brs, 2H), 6.56 (m, 2H) ppm; ${ }^{13} \mathrm{C} \mathrm{NMR}\left(\mathrm{CDCl}_{3}\right) \delta=22.1,34.4,35.9,39.7,44.1,56.3,121.1,123.2,129.2,129.8$, $129.9,218.5 \mathrm{ppm} ; \mathrm{IR}(\mathrm{KBr}) v_{\max }=3000 \mathrm{~s}, 2900 \mathrm{~s}, 1680 \mathrm{~s}, 1440 \mathrm{~s}, 850 \mathrm{~s}, 750 \mathrm{~s}, 730 \mathrm{~s} \mathrm{~cm}^{-1}$.

10. The X-ray data for $7 \mathbf{b}: \mathrm{C}_{27} \mathrm{H}_{30} \mathrm{O}_{5}, \mathrm{Mw}=434.53,0.25 \times 0.18 \times 0.12 \mathrm{~mm}^{3}$, triclinic, space group $\bar{P}(\# 2), a=10.848(1), b=13.105(2), c=8.809(1) \AA, \alpha=90.54(1), \beta=109.847(9), \gamma$ $=80.91(1) \mathrm{deg}, V=1161.7(3) \AA^{3}, Z=2, D_{\text {calc }}=1.242 \mathrm{~g} \mathrm{~cm}^{-3}, \mu(\mathrm{Cu}-K \alpha)=6.84 \mathrm{~cm}^{-1}, 3403$ independent reflections, 290 parameters, $R=0.043, w R=0.083, \mathrm{~T}=298{ }^{\circ} \mathrm{K}$. Those for 13: $\mathrm{C}_{35} \mathrm{H}_{35} \mathrm{~N}_{3} \mathrm{O}_{7}, \mathrm{Mw}=609.68,0.20 \times 0.20 \times 0.10 \mathrm{~mm}^{3}$, monoclinic, space group $P 2{ }_{1} / n$ (\#14), $a$ $=20.567(2), b=12.422(2), c=12.091(2) \AA, \beta=99.236(10), V=3049.1(6) \AA^{3}, Z=4, D_{\text {calc }}=$ $1.328 \mathrm{~g} \mathrm{~cm}^{-3}, \mu(\mathrm{Mo}-\mathrm{K \alpha})=7.63 \mathrm{~cm}^{-1}, 4133$ independent reflections, 416 parameters, $R=$ 
0.047, $w R=0.075, \mathrm{~T}=298^{\circ} \mathrm{K}$. Estimated standard deviations for the bond lengths and angles are 0.004-0.007 (ang) and 0.2-0.4 (deg), respectively, for the non-hydrogen atoms. Crystallographic data excluding structures have been deposited with the Cambridge Crystallographic Data Centre as supplementary publication numbers CCDC 621089 for $\mathbf{7 b}$ and CCDC 621088 for 13, respectively. A copy of the data can be obtained free of charge from CCDC, 12 Union road, Cambridge CB2 1EZ. UK [DIRECT LINE: +44 1223762910 , Fax: +44 (0) 1223-336033 or e-mail: 1instead@ccdc.cam.ac.uk; deposit@ccdc.cam.ac.uk.

11. PM3 calculations were carried out using MOPAC program (ver. 94.10 derived from ver. 6.00) in a package of CAChe (ver. 4.1.1, c 1998, Oxford Molecular Ltd.) program.

12. Heats of formation (in $\mathrm{kcal} \mathrm{mol}^{-1}$, parentheses are relative energies) of the syn- and antienolates are as follows; -13.39 (0) for the syn-enolate and -12.31 (1.07) for the anti-enolate. DFT calculations of two lithium enolates at the B3LYP/6-31G(d) level of theory support the results of PM3 calculations. Total energies in a.u. with zero-point correction are as follows (parentheses are relative energies in $\mathrm{kcal} \mathrm{mol}^{-1}$ ); -540.0624965 (0) for the syn-enolate and $-540.0624710(0.16)$ for anti-enolate.

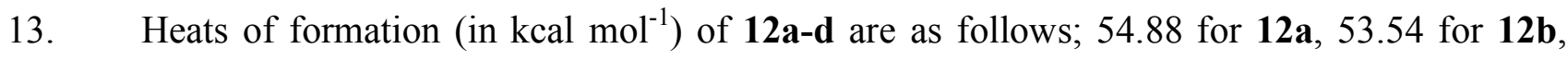
61.27 for 12c, and 65.23 for 12d. DFT calculations at the B3LYP/6-31G(d) level of theory support the results of PM3 calculations. Total energies in a.u. with zero-point correction are as follows (parentheses are relative energies in $\mathrm{kcal} \mathrm{mol}^{-1}$ ); -888.2367909 (1.00) for 12a, -888.2383892 (0) for $\mathbf{1 2 b},-888.2205374$ (11.20) for 12c, and -888.2172517 (13.26) for $12 d$.

14. For conformational analysis of eight-membered ring compounds, see; a) Hendrickson, J. B. J. Am. Chem. Soc. 1967, 89, 7047-7061; b) Rocha, W .R.; Pliego, J. R., Jr.; Resende, S. M.; Dos Santos, H. F.; De Oliveira, M. A.; De Almeida, W. B. J. Comput. Chem. 1998, 19, 524534; c) Jung, M. Bull. Korean Chem. Soc. 1999, 20, 1-8; d) Dos Santos, H. F.; Rocha, W. R.; De Almeida, W. B. Chem. Phys. 2002, 280, 31-42. 